\title{
WHY IS IT ESSENTIAL TO STUDY VERBAL MAGIC FROM WITCH TRIALS?
}

\author{
Emese Ilyefalvi
}

mseilyefalvi@gmail.com

\begin{abstract}
I analysed data about charm practices from witch trials. It is diversified and a very rich mass of material. It is more important than generalities is that while acquiring additional details of early modern charm practice, due to the characteristics of this source type, we also get an insight into the beliefs underlying charms, as well as the social, personal and contextual use and strategies of talking about these beliefs. The goal of this paper had been to show why it is indispensable from the point of view of charm research to study the source documents of witchcraft persecution.
\end{abstract}

Keywords: witch trials, Hungary, charms, rituals, early modern witchcraft

\section{INTRODUCTION}

Judit Helpári appeared before the feudal court of Diószeg on February $16^{\text {th }} 1701$, accused of witchcraft. During the hearing, witnesses were questioned about two particular instances of threat, describing in both cases the exact circumstances of the situation, the people present and the content of the threats that she had made. The court also inquired what were the motivations that triggered Judit Helpári's behaviour. They asked, in general, whether the witnesses knew of any threats that were also adequate for proving that the accused was in actual fact a witch. The witness statements leave no doubt, and later the accused herself openly admitted the fact of the threat she had made. At the same time, the pleader and the accused herself both claimed that 'the threats she made were not of a devilish nature' but 'lawful', driven purely by sentiments of maternal love, the case being that she threatened the people who wanted to persecute her son to his destruction (Schram 1970, I. 49). Did they manage to convince their judges? And what are the devilish and non-devilish ways of threatening someone?

This paper undertakes to present verbal interactions that survived in the sources of early modern Hungarian witch trials. At the beginning of my analysis, I will present witch trials as an important source type of the research on verbal magic and especially charms. Following that, I will briefly discuss the issues related to terminology, which will also shed light on the methodological background of the research. The second half of the paper will sum up the conclusions 
of the analysed trial documents, illustrating the results with a few concrete examples. Although the framework of this paper does not leave room for me to discuss in detail the dilemmas of source criticism that generally arise during the study of early modern witness testimonies and witch trial documents, at the end I will briefly touch upon charms confessed during torture interrogation procedures that are relevant from the perspective of charms research.

\section{LOOKING FOR A NEEDLE IN A HAYSTACK}

Why is it essential to examine the source material of early modern witch trials for the study of verbal magic? What additional information do they contain that other types of sources do not? Contrary to other folk genres, the phenomena can be studied through numerous types of sources, dating from Antiquity until today (to mention only a few: codices, books of recipes, marginalia, literature against superstitions, nineteenth-century newspapers, etc.). However, if we want to learn about the use or the modes of application of charms, spells, curses or the attitude and the opinion of the people who used these texts, the available source material is very meagre. It is even more so if we want to capture the practice of the illiterate and lay people of the medieval and early modern periods.

Aside from a few extraordinary sources, practically the only suitable material for this purpose would be the trial documents of medieval and early modern religious and secular legal proceedings, especially the texts of witness testimonies. The other source types allow merely the unearthing of the charm-corpus typically transmitted through writing and only occasionally the reconstruction of the oral presentation of these texts. ${ }^{1}$ In early modern witch-hunts verbal magic became one of the central elements of prosecution because according to the ideology explaining calamities, a witch is a person who casts bewitchments, and the simplest way to bewitch is through words (MacFarlane 1970; Kieckhefer 1976; Larner 1984; Pócs 1998, Bever 2006, 2013). Consequently, witch trials have richly documented the various forms of verbal magic (curse, threat, incantation, etc.); in most of the cases they even paid attention to the accuracy of the recorded text (Tuczay 2006: 182; Rider 2015; Oates 2006). We find countless examples in early modern Hungarian trials with Latin protocols where the scribes recorded the text of an incantation in the original Hungarian version; or in the trial document with Hungarian protocols the incantations were underlined for emphasis; furthermore, in the case of charm texts we often

\footnotetext{
${ }^{1}$ Borsje 2016.
} 
find the corrections and posterior modifications by the scribe. ${ }^{2}$ See examples below from the trial of Mrs. András Hagyó, 1567, Kolozsvár. ${ }^{3}$ The highlighted lines were originally Hungarian in the Latin texts.

a) [Q]uod sunt anni octodecim in capillis existens [uxor Andreae Hagyó] una cum sorore maiore quadam Elizabet summo diluculo ante auroram in festo Georgii, antequam gregem in campum expellerent, ad fores stetissent, ac illa Elizabet voce alta acclamasset: ${ }^{4}$ "Witches in my tub, milk, butter, and my shit into your tub!"

b) [Q]oud ipsa in profesto Sancti Georgii audisset et vidisset, quod in capillis existente [uxore] Andreae Hagio cum sorore quadam ad retrimentum in plateam stetissent. Et altera earum clamorem edidisset: ${ }^{5}$ Csür, csür ${ }^{6}$ Adeo quod rati fuissent testes horreum ardere. ${ }^{7}$ Milk and butter into my pumpkin dish and my tub, my shit into yours! Sed testis nescivisset de quibus fuerit loquuta. ${ }^{8}$

c) Dehinc transcendens in hortum proprium quandam ollam effodisset herbas antehac collectas in eam condens, et hoc tempore introit[us] armentorum erat hiis dictis: ${ }^{9}$ "Let my tub fill with butter and cheese, and dung into others'!" Et coram armenta exivisset et ibi discurisset. Id a propria consanguinea audisset, quod dictum uxori Andreae Hagio: cur non vivis etiam hic pacifice inter vicinos tuos, tamen scis te etiam in patria versatum esse in condemptionem propter tua facta, et etiam spine consecate erant tibi, et adhuc non servas te immunem, hic quoque non vivis pacifice. ${ }^{10}$

\footnotetext{
${ }^{2}$ Liv Helene Willumsen's paper examined Scottish witch trials and found charms in Gaelic in English and Latin context; and Raisa Maria Toiva, in relation to Finnish witch trials, draws the attention to threats and incantations in the Swedish legal text that were left in the original Finnish version without translation. (Willumsen 2011: 542; Toivo 2012: 148-149.)

${ }^{3}$ Komáromy 1910: 14-15; Ilyefalvi 2014: 180-181.

${ }^{4}$ That it has now been eighteen years since Mrs. András Hagyó, then still unmarried, and her sister Erzsébet, stood by the door one morning early, at dawn, before sunrise, before the herd was driven out, on St. George's Day, and that Erzsébet called out in a shrill voice [...].

${ }^{5}$ That she herself had seen and heard on St. George's Day that Mrs. András Hagyó, then still unmarried, stood in the street with one of her sisters. And one of them heard a call [...].

${ }^{6}$ Words used perhaps as onomatopoeic imitations of spitting and clacking (clicking?) the tongue.

${ }^{7}$ So much so that the witnesses believed that they were to pluck up courage to do something fearful.

${ }^{8}$ But the witness did not know what they were talking about.

${ }^{9}$ Going over from here into her own garden she buried the pot, putting into it the herbs she had collected beforehand, she did this as the cows were brought in, she said,

${ }^{10}$ She went out to meet the cows and walked up and down in front of the herd. She heard it from a relative as told to Mrs. András Hagyó, Why don’t you live in peace at least here among your neighbors? You know that they raised charges against you in your own country for your doings and reproached you for your sins, and still you cannot feel innocent until you learn to live in peace here.
} 
Nonetheless, research has so far dedicated little attention to charms in witch trials. Although historians, historical anthropologists and folklorists dealing with early modern European witchcraft, concerning maleficium narratives, have been emphasising, since the 1970s, the role of the malefactor witch who casts bewitchment with curses and threats, few have focussed their analysis and interpretation on the dialectics and personal interpretations of the various genres of verbal magic such as charms, threats, curses or profanities (Labouvie 1992, 1993; Leitner 2017). All this is not surprising, since archivists and researchers of early modern history are not interested in the practice of charms; moreover, in Western Europe, the study in historical anthropology and microhistory, the monographic discussion of one region, village or problem are only rarely accompanied by source editions. ${ }^{11}$ The study of charms documented from early modern orality, however, requires source editions and historical corpuses; researchers cannot go to archives looking for charms documented in one way or another from orality, because it would be similar to looking for a needle in a haystack. ${ }^{12}$

In the case of Hungary, fortunately there is no need to go to archives, since Hungarian witchcraft research was motivated and characterised by a significant interest in historical folkloristics and anthropology from the very beginning; and since the $1980 \mathrm{~s}$, besides the discovery and analysis of trial documents, the publication of sources was of primal importance, precisely with the aim of making the material available to other disciplines as well. For instance, they ensure source material for the study of early modern belief systems carried out by folklorists. ${ }^{13}$ As a result of this work, the documents of more than 2000 trials are available in printed versions. The historian and ethnographer Péter Tóth G. is currently working on uploading the trial texts into a digital database. ${ }^{14}$ Thus, for my analysis, I had several thousands of pages of early modern witch trials in Hungarian in a searchable format at my disposal. On the one hand, this was a unique opportunity, considering the monumental size of the corpus covering approximately 300 years. The digitized version allowed instant search by expression or word (such as 'incantation', 'curse', 'threat', 'prayer'). On the other hand, since the corpus is not invested with semantical annotations, and the language use of early modern Hungarian speakers was very diverse (multilingualism, mixed or bilingualism, dialectological differences etc.), which was

${ }^{11}$ The Scottish witch trials constitute an exception to this. For the different sources of witchcraft see: Monter 2006.

${ }^{12}$ This is also well reflected in text editions including charms in historical sources, which only rarely contain charms from witch trials or from any legal proceedings.

${ }^{13}$ For the history of Hungarian research on early modern witch-hunting see: Tóth G. 2001. For the most important general information and statistics in English see: Sz. Kristóf 2013. And for the most important English publications of the research group and its predecessors see: Klaniczay \& Pócs (eds.) 1991, 2008, 2017; Pócs 1998, 2001.

${ }^{14} \mathrm{http}: / /$ boszorkanykorok.hu/ Last accessed: 28.11 .2018 
only further diversified by the varied writing practices of scribes recording the trials, an immense knowledge of vocabulary, word stems and a preliminary background knowledge of the topic is required for reaching meaningful results. All this is further complicated by the continuously changing scholarly publication practices of the past fifty years. Even though the source editions are supposed to be exact transcriptions, they are in reality on different degrees of transcription and vary by publisher and by researcher. Analysis carried out on the basis of second-hand source editions has its drawbacks; in my paper, however, I want to focus on the advantages; that is, on the useful conclusions of analyses carried out on a philologically 'dirty', but large corpus.

Beyond the problems of source criticism, the investigation is further complicated by the terminological and theoretical dilemmas of the research on verbal magic. ${ }^{15} \mathrm{It}$ is often very difficult to apply to the corpus the wide interpretation and the functional definition of verbal magic (any text or genre can be a charm if it is used in the function of charms; that is, if the speaker uses words with the aim of inducing positive or negative change), since the intention of the speaker is not necessarily clear from the situation. However, the judges and the magistrate in the early modern era were driven precisely by this strict, functional approach, going beyond genre classification, since their primary goal was to prove the accusation of bewitchment and not to explore the speakers' knowledge of genres. Thus, the interrogators asked about the use of 'such' or 'diabolical words', about 'superstitious benedictions', 'unusual prayers' in various ways. For instance, in 1727 in Bagota (Bohatá) in Komárom County, they put the following question to the witnesses: "has the accused used charms or other prayers that are otherwise pious or in God's liking to heal an illness; [if yes] how many times and on whom?" (Klaniczay \& Kristóf \& Pócs 1989, I: 504-505).

For my present analysis, I used the new edition of Hungarian charms published in 2014, for which I have collected the charm texts manually from the complete witch trial corpus (Ilyefalvi 2014: 179-219). The edition focussed, on the one hand, on texts that could be defined as charms on the basis of their contexts; which means that I have not taken into consideration the emic vocabulary of the speaker and of the scribe recording the speaker (the following definitions could be found before the text: 'replied', 'said', 'answered', 'prayed', 'charmed', 'cursed', etc.). On the other hand, however, due to the classical concept of a folkloristic text collection, the edition does not include the stereotypical curses and threats, which are otherwise omnipresent in the trials. Consequently, chapter $\mathrm{F}$ of the volume is rather a collection of healing charms and verbal love magic, and not that of all occurrences of verbal magic. The volume contains six

${ }^{15}$ It was also a continuous challenge for researchers educated in theological and demonological literature to distinguish between the genres (such as prayer - benediction - charm) from the late Middle Ages on (Bailey 2006). 
texts from the sixteenth century, seventeen from the seventeenth century and almost sixty charms form the eighteenth century. This corpus was completed for this analysis with cases in which the emic wording of the trial suggested that the characters were referring to charming. The trials mention the practice of charms much more often than they contain the actual charm text.

\section{CHARMERS AND FUNCTIONS - RITES AND GESTURES}

In most cases the social status, social background and personal life path of the person practicing charms are impossible to reconstruct; nonetheless, generally speaking they were mostly serfs, landless peasants, shepherds or simple village or city women. In many cases those who practiced positive magic (wise women, seers or midwives) also practiced charms, and were suspected of witchcraft precisely because of such activities. About eighty percent of the accused were women, which was well reflected in the ratio of women among charmers, since there are only two charm-texts that survived where the accused were men. There are even two among the trials from the aristocratic milieu that stand out because of their rich references to charms: the early seventeenth-century trial of Kata Török from Medgyes (Mediaș) and the trial series against Anna Benkố from Háromszék County (Comitatul Trei Scaune) from the mid-eighteenth century.

Among historical sources, the documents of witch trials show the most diverse picture regarding the function of charms; besides healing incantations, we find data on charms used for bewitchment, preventing bewitchment, divination, love magic, treasure seeking, expelling frogs, exorcism, changing location with magic spells, causing drought or hail, transforming someone into an animal, ensuring favourable judicial results or the release from prison, as well as on ensuring good business for tavern-keepers. In a trial conducted in 1648, for instance, one of the witnesses alleged that Mrs Pál Szabó was released from the Miskolc prison thanks to a charm; in 1733 (Schram 1970, I: 133), during a procedure in Máramarossziget (Sighetu Marmației), the accused and a companion put the rope of a hanged man on a tavern's trade-sign, then poured mead in a bowl and had someone say a charm on it for good business (Tóth G. 2005: 105).

Even more important additions can be learned from witness testimonies explaining in detail the rites and gestures carried out while practicing charms. Besides massaging, palpating and rubbing, the witnesses describe in certain cases with exceptional precision frequently spitting and licking. In 1670, in Nagybánya (Baia Mare), Mrs Gergely Nagy first licked the two cheeks of a sick child and then spat next to it, then licked the child again and finally spat saliva between the eyes of the mother. In the same trial, we read that in order 
to successfully start breastfeeding, Mrs Gergely Nagy wiggled the footwrap of the husband with some vinegar around the breasts of the nursing mother while blowing on it (Balogh 2004: 81, 83). Mrs Mátyás Nagy, in 1715 in Békés County, in order to heal a woman, measured her with a stem of a hop plant, on which she tied three knots every day for three months (Klaniczay \& Kristóf \& Pócs 1989, I: 88). In 1742 in Kraszna (Crasna) the midwife, called to a patient with epilepsy, said a charm, yawned, then stuck her knife a few times in the bed board. Afterwards, she stuck the knife in the ground and carved a little hole in it with the knife, then sent one of the relatives to bring water, with the instruction to draw the water downstream. She poured a little water into the hole, then she had the patient drink from it and also washed and rubbed the region around the heart with the water from the hole while saying charms and yawning (Kiss \& Pál-Antal 2003: 209). The gestures and rites were not only assigned to healing charms. In 1705 in Nagybánya, according to a witness, for confronting the deliberating judges, the accused took earth from the graves of twelve former jurors and sprinkled the dust in the town hall while saying: "As those dead bodies cannot speak, / so should the council keep their mouths shut!" (Balogh 2004: 195).

The rites, gestures and functions of the texts are essential elements of the research on charms; fortunately, these often become apparent from other manuscript forms besides witch trials. However, the trials also contain additional contextual information that we would not find in any other source type. Where did the charm take place and who was present? How long did the treatment last? How does one acquire the knowledge of charms? Who enunciates the charm, the charmer or the patient? How do charmers heal themselves? What compensation does the charmer receive? We still have very little information regarding these questions, even in light of twentieth-century folkloristic and anthropological field studies. ${ }^{16}$ In a 1739 case in Zilah (Zalău), the twenty-oneyear-old Barbara Horvát explained in her testimony that the accused midwife performed the ritual of water casting together with another woman, and despite her wanting to be in the room to see what and exactly how they do it, she was locked out and could only observe the ritual by peeking through the window and she could not see the events properly (Kiss \& Pál-Antal 2003: 200). This

\footnotetext{
${ }^{16}$ The problem was already identified in the nineteenth century by a folklorist who collected charms. See Stiùbhart's study on the Scotsman Alexander Carmichael and his charm collecting journeys in the second half of the nineteenth century (Stiùbhart 2014) In general, it can be said that the editors of twentieth-century charm collections paid less attention to the ritual narratives and the way of narration in their publication practice; they were rather focusing on the actual text itself. This problem of collection methodology is still an issue in the twenty-first century. Even in the case of a longer fieldwork based on participant observation, it is relatively rare to be present to witness the actual act of charming, unless it is the researcher who is being treated by the charmer. For this see the anthropological field experiences of James A. Kapaló (Kapaló 2011a; 2011b: 171-172).
} 
case accentuates seclusion and the secret, prohibited side of healing, which can be illustrated with numerous examples. The same goes for the phenomenon that even if there are others present during charming, due to the silent, whispering and slow parlance of the charmer they cannot understand or hear the pronounced text (Schram 1970, II: 184; Klaniczay \& Kristóf \& Pócs 1989, I: 158-159). ${ }^{17}$ In other cases, however, the public is apparently not excluded; it would definitely be worthy of further investigation to examine the relationship between secrecy and the type of illness or other functions of charms. In Felsóbánya (Baia Sprie), Márton Csiszár was ill and sat on a threshold and a Wlach woman said a charm on him there and then, which was witnessed by the person giving the testimony, who was on his way home from the garden at the time (Klaniczay \& Kristóf \& Pócs 1989, I: 683). Occasionally, it is not even necessary for the charmer to be present in order to perform a charm. On 1726 Hegyközpályi (Paleu), Mrs Gáspár Balázs asked Mrs Pál Paládi what kind of hair her pig had because if she knew, she could name the animal and then, she claimed, she would be able to drive the worms out of it even if it were on the other side of the River Tisza (Komáromy 1910: 366). According to the trials, charming is sometimes a onetime thing, which has an immediate effect; in other cases, it is part of a cure or a treatment lasting for weeks or even months.

Regarding the practice of transmitting the oral tradition the historical sources contain little information; in the protocols of witch trials, however, there are important data about this as well. In several cases we read, for instance, about the patient who learned the charms on the occasion of a previous healing; that is, from the person who once healed the patient. In 1727, Judit Jászberényi from Nyitra County (Nitriansky komitát) learned the incantation for sprains from a certain late Mrs Csákány when she healed her foot with charms (Klaniczay \& Kristóf \& Pócs 1989, I: 504). In 1752, Mrs György Horváth from Magyarnádalja also testified to having learned the charm's text during a treatment and later applied it on herself (Schram 1970, II: 728). In addition, we do have a few references of transmitting the tradition within the family. In 1752 in Kiskunmajsa, the testimony of Mrs Gergely Bozsér, accused of witchcraft, reveals that she had learned the healing prayer from her mother (Bessenyei 2000, II: 288). In certain cases, the specialist taught the mother of the sick child to charm and to perform the ritual.

\footnotetext{
${ }^{17}$ In a multilingual environment, witnesses often claimed that the reason they did not understand what the charmer said was that the charm was pronounced in another language (for instance, Romanian, Croatian, etc.). See for instance in 1674 in Croatian Schram 1970, II. 709; or in 1727 in Felsőbánya in Romanian, (Klaniczay \& Kristóf \& Pócs 1989, I. 682).
} 


\section{EMIC INTERPRETATIONS}

The biggest novelty of witch trials as sources of the research on charms, however, was not all of the above, but the unique insider perspective. This is the point at which we turn back to the example quoted at the beginning of the paper, i.e. the case of Judit Helpári. This woman from Diószeg did well in front of the courts - although her prosecutor would have willingly sent her to the stakes eventually she was acquitted. This lenient verdict may partially have been related to the fact that her accusers could not offer a bewitchment narrative in which the threat was followed by actual harm, and also that no other charge beyond the named instances of threat occurred in the case of Mrs. Aradi. However, it is instructive from the perspective of the study of verbal magic that in the early $18^{\text {th }}$ century it was possible to make a meaningful distinction between a threat uttered under a strong emotional impulse and a 'devilish threat.' A threat that was expressed as a result of maternal love 'feeling bitter and meaning the thing in a lawful manner' did not constitute a proof of witchcraft.

The actors in the situations described by witness testimonies often react to certain phenomena of verbal magic, they comment on it or interpret for themselves what they saw and heard. Naturally, when studying these interpretations, we must not forget that firstly they were speaking in a courtroom situation with specific intentions that could have shaped the content of their testimonies. However, the enunciated interpretations are possible and acceptable interpretations and valid expressions of the speakers, thus, they do have a source value to us. In the 1660s in Nagybánya, for instance, a patient instructed the healer woman "not to use charms, only to rub her", as if she were refraining from being treated with such superstitious practices (Balogh 2004: 60). Others did the opposite and tried to accentuate the religious, Christian nature of the texts, thus legitimising the healing procedure they were treated with, by using expressions such as 'Godly prayer', 'healing with Godly methods' (Klaniczay \& Kristóf \& Pócs 1989, I: 504-505). In a crisis situation, one has to follow a specific behavioural norm, but not everybody was able to comply with this norm. In 1684 in Nagybánya, a servant of the family started to laugh when the healer was about to start charming, for which the midwife inflicted him with a lifelong bewitchment, according to the trial narrative (Balogh 2004: 104). In other cases, we see that, even though they receive precise instructions for the procedure, they do not 'dare' to carry out the ritual (Pakó \& Tóth G. 2014: 157) or simply doubt its mechanism. In the trial series of Anna Benkó in Háromszék, one of the witnesses recalled a situation when Anna Benkó told the Romanian Gypsy woman who performed love magic that "this was about as useful as a horse shoe for a dead horse” (Klaniczay \& Kristóf \& Pócs 1989, I: 334). 
The different personal interpretations, verbal interactions, habits and attitudes corresponding to the situation highlight an important aspect of verbal magic-practices. On the one hand, they show that despite any text being suitable to have the function of a charm (and in certain crisis situations the charmers did not select among the texts) and despite the fact that the tribunals were also primarily interested in proving the accusation of witchcraft, the early modern charm users did, however, distinguish between different kinds of verbal magic; and not only to prove their or their neighbour's innocence or guilt. They discussed verbal magic mostly from the perspective of the charm's intention and function (a frequently used defence strategy of the charmers was to claim that they only knew texts to heal certain illnesses, such as bewitchment, aches, skin conditions, and no other), the content of the text and its presumed effect, as well as from the point of view of the emotional state of the utterancer. On the other hand, we can see how the actors use charms and narratives about charms in a judicial context serving the ideology of persecution.

\section{CHARMS FROM TORTURE INVESTIGATIONS}

The 'great' Szeged witch trial at the end of the 1720s was the only mass persecution and trial series that took place in the history of early modern Hungarian witchcraft, during which numerous torture confessions were extracted (Brandl \& Tóth G. 2016). During torture, the interrogators asked the accused the question whether they used 'superstitious benedictions'. Some confessed the simplest, ordinary texts associated with ordinary work rituals, for instance when planting millet seeds she used to say: "You plant the millet, may it grow tall!" However, some of the witnesses confess to having said texts that, in light of the entire charm-corpus, can be considered unusual. According to one witness, they healed a girl by saying the following charm: "We bewitched her in the devil's name / now we want to heal her in his name". Another witness confessed that while the participants were dancing with whistles and drums they said: "We are the troops of Beelzebub. With the fame of szotypiri tantiri". Mentioning the devil and naming him by name, changing location or shape by saying the Lord's prayer backwards or by saying the words "hipp-hopp" or a variant of it, are almost exclusively only known from torture confessions (Brandl \& Tóth G. 2016: 119, 126-129, 150, 162). Charms forced out with torture interrogation of the accused show clearly which texts the accused considered to belong surely to the prohibited sphere of magic; and consequently, which were the texts that they could confess, with the hope that they would perhaps escape. 


\section{CONCLUSION}

In my paper, I analysed data about charm practices from witch trials. It is difficult to draw general conclusions from the diversified and very rich mass of material. However, what is more important than generalities is that while acquiring additional details of early modern charm practice, due to the characteristics of this source type, we also get an insight into the beliefs underlying charms, as well as the social, personal and contextual use and strategies of talking about these beliefs. The goal of this paper had been to show why it is indispensable from the point of view of charm research to study the source documents of witchcraft persecution. It was meant as a programmatic reminder for later systematic analyses to point out the importance of certain topics that are waiting to be examined. By analysing the trial material we may gain a glimpse into such areas of the charm tradition which hardly any other source can provide. The witness accounts offer examples as to who the charmers were and to what ends they deployed the power of words; where the healing/bewitchment took place and who were the persons present (whether secretly or overtly); who uttered the text and what sort of compensation was given to the healer; how did the knowledge transfer take pace. We can read detailed descriptions of rituals and gestures, often accompanied by explanations of the beliefs they rest upon. As regards witness statements from confessions made under torture, these highlight the way in which the method of acquiring the data influences the textual material recorded. At the same time, from the point of view of exploring the genre itself, the most important thing is that these witness statements enable us to comprehend the phenomenon from the perspective of the contemporary 'user.' Charm researchers working on the historical material are still finding it difficult, in spite of repeated criticisms, to leave behind such anachronistic binary oppositions as magic vs. religion or charm vs. prayer (cf. Fisher 2016, Borsje 2016). Based on the witness statements we may attempt to discard such etic categories.

\section{AKNOWLEDGEMENTS}

Supported by the ÚNKP-18-3 New National Excellence Program of the Ministry of Human Capacities. 


\section{REFERENCES}

\section{Source Editions of the Hungarian Witchraft Trials:}

Balogh, Béla (ed.) 2003. Nagybányai boszorkányperek [Witchcraft Trials of Nagybánya]. A magyarországi boszorkányság forrásai, várostörténeti források 1. Budapest: Balassi Kiadó.

Bessenyei, József (ed.) 1997-2000. A magyarországi boszorkányság forrásai [Sources of the Hungarian Witchcraft Trials]. 2 vols. Budapest: Balassi Kiadó.

Brandl, Gergely \& Tóth, G. Péter (eds.) 2016. Szegedi boszorkányperek [Witchcraft Trials of Szeged]. A magyarországi boszorkányság forrásai, várostörténeti források 5. Budapest: Balassi Kiadó.

Kiss, András \& Pál-Antal, Sándor (eds.) 2002. A magyarországi boszorkányság forrásai [Sources of the Hungarian Witchcraft Trials] Vol. 3. Budapest: Balassi Kiadó.

Klaniczay, Gábor \& Kristóf, Ildikó \& Pócs, Éva (eds.) 1989. Magyarországi boszorkányperek. Kisebb forráskiadványok gyújteménye. [Hungarian witch trials. Collection of minor source publications] 2 vols. Budapest: MTA Néprajzi Kutatócsoport.

Komáromy, Andor 1910. Magyarországi boszorkányperek oklevéltára. [Source-book of Hungarian witch trials.] Budapest: MTA.

Pakó, László \& Tóth G., Péter (eds.) 2014. Kolozsvári boszorkányperek, 1564-1743 [Witchcraft Trials of Klausenburg, 1564-1743]. A magyarországi boszorkányság forrásai, várostörténeti források 4. Budapest: Balassi Kiadó.

Schram, Ferenc (ed.) 1970-1982. Magyarországi boszorkányperek, 1529-1768. [Hungarian Witchcraft Trials]. 3 vols. Budapest: Akadémiai Kiadó.

Tóth G. Péter (ed.) 2005. A magyarországi boszorkányság forrásai [Sources of the Hungarian Witchcraft Trials]. Vol. 4. Budapest: Balassi Kiadó.

\section{Secondary literature:}

Bailey, Michael D. 2006. The Disenchantment of Magic: Spells, Charms, and Superstition in Early European Witchcraft Literature. The American Historical Review 111, no 2. pp. 383-404.

Bever, Edward. 2006. Curses. In: Richard M. Golden (ed.) Encyclopedia of Witchcraft: The Western Tradition. California: ABC CLIO, pp. 241-243.

Bever, Edward. 2015. Popular Witch Beliefs and Magical Practices. In: Brian P. Levack (ed.) The Oxford Handbook of Witchcraft in Early Modern Europe and Colonial America. Oxford: Oxford University Press, pp. 50-68.

Borsje, Jacqueline 2016. Medieval Irish Spells: "Words of Power" as Performance. In: E. van den Hemel, A. Szafraniec (eds.) Words: Religious Language Matters. Fordham University Press, pp. 35-53.

Dinzelbacher, Peter 2006. Spells. In: Richard M. Golden (ed.) Encyclopedia of Witchcraft: The Western Tradition. California: ABC CLIO, pp. 1077-1078. 
Fisher, Rebecca M. C. 2016. Genre, Prayers and Anglo-Saxon Charms. In: Kaarina Koski, Frog, Ulla Savolainen (eds.) Genre - Text - Interpretation. Multidisciplinary Perspectives on Folklore and Beyond. Helsinki: Finnish Literature Society, pp. 137-151.

Ilyefalvi, Emese 2014. Bevezetó. [Introduction] In: Emese Ilyefalvi (ed.) Ráolvasások. Gyüjtemény a történeti forrásokból (1488-1850). [Charms. Collection from historical sources (1488-1850)] A magyar folklór szövegvilága 2/B, Budapest: Balassi Kiadó, pp. 11-37.

Ilyefalvi, Emese (ed.) 2014. Ráolvasások. Gyújtemény a történeti forrásokból 1488-1850. [Charms. Collection from historical sources (1488-1850)] A magyar folklór szövegvilága 2/B. Budapest: Balassi Kiadó.

Kapaló, James A. 2011a. Genre and Authority in the Genesis of Charm and Prayer. Incantatio 1, no. 1. pp. 79-101.

Kapaló, James A. 2011b. Text, Context and Performance: Gagauz Folk Religion in Discourse and Practice. Numen Book Series: Studies in the History of Religions, 135. Leiden-Boston: Brill.

Kieckhefer, Richard. 1976. European Witch Trials: Their Foundations in Popular and Learned Culture, 1300-1500. London: Routledge \& KPaul.

Klaniczay, Gábor \& Pócs, Éva (eds.) 1991. Witch beliefs and witch-hunting in Central and Eastern Europe. Acta Ethnographica Hungarica 37, no. 2.

Klaniczay, Gábor \& Pócs, Éva (eds.) 2008. Witchcraft Mythologies and Persecutions. Demons, Spirits, Witches 3. Budapest: CEU Press.

Klaniczay, Gábor \& Pócs, Éva (eds.) 2017. Witchcraft and Demonology in Hungary and Transylvania. Palgrave Historical Studies in Witchcraft and Magic. Houndmills: Palgrave Macmillan.

Kristóf Sz., Ildikó 2013. Witch-Hunting in Early Modern Hungary. In: Brian P. Levack (ed.) The Oxford Handbook of Witchcraft in Early Modern Europe and Colonial America. Oxford: Oxford University Press, pp. 334-354.

Labouvie, Eva 1992. Verbotene Künste: Volksmagie und ländlicher Aberglaube in den Dorfgemeinden des Saarraumes (16-19. Jahrhundert). St Ingbert, Röhrig Verlag.

Labouvie, Eva 1993. Verwünschen und Verfluchen: Formen der verbalen Konfliktregelung in der ländlichen Gesellschaft der Frühen Neuzeit. In: Peter Blickle (ed.) Der Fluch und der Eid: Die metaphysische Begründung gesellschaftlichen Zusammenlebens und politischer Ordnung in der ständischen Gesellschaft. Zeitschrift Für Historische Forschung, 15. Berlin: Duncker \& Humblot, pp. 121-145.

Larner, Christina 1984. Witchcraft and Religion: The Politics of Popular Belief. Oxford: Blackwell.

Leitner, Magdalena 2017. Curses or Threats? Debating the Power of Witches. Words in 17th-Century Scottish Courtrooms. Nordic Journal of English Studies 16, no. 1. pp. $145-170$.

Macfarlane, Alan. 1970. Witchcraft in Tudor and Stuart England. A Regional and Comparative Study. London: Routledge and Kegan Paul.

Monter, William 2006. Sources for witchcraft trials. In: Richard M. Golden (ed.) Encyclopedia of Witchcraft: The Western Tradition. California: ABC CLIO, pp. 1065-1068.

Oates, Caroline 2006. Words, power of. In: Richard M. Golden (ed.) Encyclopedia of Witchcraft: The Western Tradition. California: ABC CLIO, pp. 1224-1227. 
Pócs, Éva 1998. Between the Living and the Dead: A Perspective on Witches and Seers in the Early Modern Age. Budapest: Central European University Press.

Pócs, Éva 2001. Preface: Fifteen Years of a Research Team. In: Éva Pócs (ed.) Demonológia és boszorkányság Európában. Studia Ethnologia Hungarica 1. Budapest: L'Harmattan; PTE Néprajz Tanszék, pp. 337-346.

Rider, Catherine 2015. Common Magic. In: David J. Collins. (ed.) The Cambridge History of Magic and Witchcraft in the West. From Antiquity to the Present. New York, NY: Cambridge University Press, pp. 303-331.

Stiùbhart, Domhnall Uilleam 2013. The Making of a Charm Collector. Alexander Carmichael in Uist, from 1864 to 1882. In: James A. Kapaló, Éva Pócs, William F. Ryan (eds.) The Power of Words. Studies on Charms and Charming, in Europe, Budapest: CEU Press, pp. 27-70.

Toivo, Raisa Maria 2012. Discerning Voices and Values in the Finnish Witch Trials Records. Studia Neophilologica 84. pp. 143-155.

Tóth G. Péter 2001. Boszorkányos hagyaték. A magyarországi boszorkányság feltárásának kutatástörténet a kezdetektól napjainkig [Witchcraft legacy. A history of exploration of witch trials in Hungary from the beginning to present] In: Gábor Vargyas (ed.) Párbeszéd a hagyománnyal. A néprajzi kutatás múltja és jelene. Tudományos konferencia a PTE Néprajz-Kulturális Antropológia Tanszék jubiláló professzorai: Andrásfalvy Bertalan, Filep Antal, Kisbán Eszter és Pócs Éva tiszteletére. (Studia Ethnologica Hungarica XIII.) Budapest-Pécs: L'HarmattanPTE Néprajz Tanszék, pp. 637-694.

Tuczay, Christa 2006. Charms. In: Richard M. Golden (ed.) Encyclopedia of Witchcraft: The Western Tradition. California: ABC CLIO, pp. 181-182.

Willumsen, Liv Helene 2011. A Narratological Approach to Witchcraft Trial: A Scottish Case. Journal of Early Modern History 15, no. 6. pp. 531-560.

\section{BIO}

ORCID: https://orcid.org/0000-0001-6677-5843

e-mail address: ilyefalvi.emese@btk.elte.hu

Emese Ilyefalvi studied folkloristics, religious studies and philology at Eötvös Loránd University, Budapest. She worked from 2013 to 2018 as a junior research fellow in the "East-West" Research Project ("Vernacular religion on the boundary of Eastern and Western Christianity: continuity, changes and interactions" ERC project No 324214). Within the framework of this project, she published a new Hungarian charm collection in 2014 co-authored with Éva Pócs and the Digital Database of Hungarian Verbal Charms in 2018. (See: http://raolvasasok.boszorkanykorok.hu/) She finished her $\mathrm{PhD}$ Thesis in 2019 about the theoretical, methodological and technical questions of computational folkloristics. She published several articles in Hungarian and international 
journals (Ethnographia, Replika, Incantatio) on these topics. She was a visiting scholar in Vienna (Collegium Hungaricum Wien), in Amsterdam (University of Amsterdam) and in Edmonton (University of Alberta, Wirth Institute for Austrian and Central European Studies.) Since 2013, she has been giving lectures and seminars related to her research at Eötvös Loránd University and the University of Pécs. At present, she is an assistant professor at the Department of Folkloristics (Eötvös Loránd University, Budapest, Hungary) and a research fellow at MTA-ELTE Lendület Historical Folkloristics Research Group. 